Several lines of research indirectly suggest that platelet activating factor (PAF) may intervene in the path ogenes is of extrin sic allergic alveolitis (EAA). The specific aim of our study was to evaluate the participation of PAF on macrophage activation during the acute phase of EAA in an experimental model of this disease developed in guinea pigs. In itially we measured the concentration of PAF in bronchoalvedar lavage fluid, blood and lung tissue. In a second phase we evaluate the participation of PAF on alveolar macrophage activation and parenchymal lung injury. The effect of PAF on parenchymal lung injury was evaluated by measuring several lung parenchymatous lesion indices (lung index, bronchoalvedar lavage fluid (BALF) lactic hydrogenase activity and BALF alkaline phosphatase activity) and parameters of systemic response to the challenge (acute phase reagents). We observed that induction of the experimental EAA gave rise to an increase in the concentration of PAF in blood and in lung tissue. The use of the PAF-receptor antagonist BN52021 decreases the release of lysosomal enzymes ( $\beta$-glucuronidase and tartrate-sensitive acid phosphatase) to the extracellular environment both in vivo and in vitro. Furthermore, antagonism of the PAF receptors notably decreases pulmonary parenchymatous lesion. These data suggest that lung lesions from acute EAA are partly mediated by local production of PAF.

Key words: platelet activating factor, alveolar macrophage, extrinsic allergic alveolitis

\section{BN 52021 (a platelet activating factor-receptor antagonist) decreases alveolar macrophage-mediated lung injury in experimental extrinsic allergic alveolitis}

\author{
J-L. Pérez-Arellano, ${ }^{1, C A}$ T. Mart' $n^{2}$, J-M. \\ López-Novoa, ${ }^{3}$ M-L. Sánchez, ${ }^{2}$ A. Montero ${ }^{3}$ and \\ A. Jiménez ${ }^{1}$
}

${ }^{1}$ Department of Clinical Sciences-1, Universidad de las Palmas de Gran Canaria Facultad de Ciencias de la Salud, Plaza Dr Pasteur. Trasera Hospital Insular, 35080 Las Palmas de Gran Canaria; ${ }^{2}$ Departments of Medicine and ${ }^{3}$ Physiology and Pharmacology, Universidad de Salamanca, Spain

\author{
${ }^{\mathrm{CA}}$ Corresponding Author \\ Tel: $(+34) 28451455$ \\ Fax: (+34) 28451413 \\ Email: jluisper@idecnet.com
}

\section{Introduction}

Extrinsic allergic alveolitis (EAA) are a group of lung diseases that result from repeated exposure to some antigenic organic dusts. ${ }^{1}$ The disease mainly affects the distal airways and is characterized by interstitial and alveolar inflammation often associated with granulomas. ${ }^{2}$ EAA is a model of considerable interest in the study of the pathogenic mechanisms of interstitial lung diseases since in this disease alveolitis is more intense. ${ }^{3}$

Alveolitis is the key pathogenic process in all interstitial diseases and is characterized by two fundamental features: an increase in the number of alveolar cells and the activation of these cells. Although the type of inflammatory response varies in different species, in all the EAA models there is a marked increase in the number of alveolar macrophages (AM), thus implying that this cell type plays an essential role in the pathogenesis. ${ }^{3,4}$ In EAA the AMs are activated, and in response to the causal antigens they release a large number of inflammatory mediators (i.e. lysosomal enzymes, oxygen free radicals, cytokines, arachidonic acid metabolites) capable of injuring the lung parenchyma. ${ }^{5}$ Specifically, our group has demonstrated the role of lysosomal enzymes both in clinical ${ }^{6}$ and experimental ${ }^{7}$ EAA.

Diverse data suggest that platelet activating factor (PAF) participates in the pathogenesis of the acute phase of EAA: (a) the pathological data observed in patients with EAA and in animals subjected to models of this disease are similar to those obtained after intratracheal administration of $\mathrm{PAF}^{8}$ (b) AMs synthesize and release PAF in response to diverse stimuli ${ }^{9-11}$ and also have PAF receptors, ${ }^{12,13}$ and (c) one of the effects of PAF on cells of the mononuclear phagocyte system is the activation of these cells and the release of different mediators (among which are lysosomal enzymes). ${ }^{14,15}$

Hence, the specific aim of our study was to evaluate the participation of PAF in two basic aspects of the acute phase of extrinsic allergic alveolitis: macrophage activation and monocyte recruitment.

\section{Material and Methods}

\section{Materials}

Faenia rectivirgula (CECT 3223) was kindly provided by the Departamento de Microbiologia (Facultad de 
Ciencias Biológicas, Universidad de Valencia). This strain which corresponds to ATCC 15347. F. rectivirgula was inoculated into trypticase-soy broth and grown at $52^{\circ} \mathrm{C}$ for 6 days in a shaking incubator. It was harvested by centrifugation at $450 \times \mathrm{g}$ and washed three times with sterile saline. Cell walls were disrupted with a Polytron homogenizer (Kinematica, Kriens/Luzern, Switzerland) and the mixture was then sonicated (Sonifier, Branson Sonic Power Company, Danford, CT) three times (20 periods). The lysate was lyophilized and stored in sterile vials. BN 52021 was kindly provided by P. Braquet (IPSEN, 30 Rue Cambrone, Paris).

\section{Animal model of extrinsic allergic alveolitis}

Male Dunkin-Hartley guinea pigs (200-250g, IFFA Credo, Spain) were used for all studies. Principles of Laboratory Animal Care, formulated by the National Society for Medical Research were used as guidelines for the use and care of animals. Guinea pigs were housed in sterile rooms and were allowed food and water ad libitum. Intramuscular injection of ketamine $(100 \mathrm{mg} / \mathrm{ml}$ body weight) for anaesthesia. EAA was induced according to the protocol of Schuyler and Crooks ${ }^{16}$ with minor modifications ${ }^{7}$ (Fig. 1). Lyophilized antigen was resuspended in pyrogen-free saline at $4 \mathrm{mg} / \mathrm{ml}$ and administered intratracheally at $3.6 \mathrm{mg} / \mathrm{kg}$ body weight. F. rectivirgula antigen $(1.6 \mathrm{mg})$ was emulsified in $400 \mu \mathrm{l}$ of complete Freund adjuvant (Sigma F-5881) for intramuscular inoculation, or in $400 \mu \mathrm{l}$ of incomplete Freund adjuvant (Sigma F-5506) for subcutaneous administration. Each experimental group comprised six animals and a control group of six normal guinea pigs was also included in the study. All procedures were performed using standard sterile materials. In a previous work our group has demonstrated that saline intratracheal inoculation did not modifies the parameters evaluated when compared with control group. ${ }^{7}$

\section{In vivo administration of BN 52021}

The PAF receptor antagonist BN 52021 was diluted daily in pyrogen free saline and inoculated intraperitoneally at $5 \mathrm{mg} / \mathrm{kg}$ body weight. ${ }^{17}$ The administration schedule is shown in Fig. 1.

\section{Collection of samples}

Two hours after the last intratracheal challenge with Faenia rectivirgula antigen, the guinea pigs were sacrificed. Bronchoalveolar lavage (BAL) was performed using $12 \mathrm{ml}$ of pyrogen-free saline in three

Control group

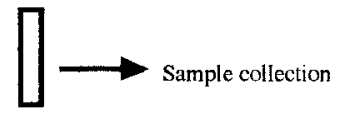

Control group

+ BN 52021

Acute Extrinsic allergicalveolitis

Acute Extrinsic allergic
alveolitis +
BN 52021

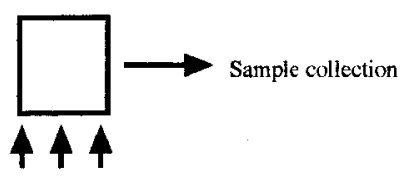

Intraperitoneal BN 52021 inoculation

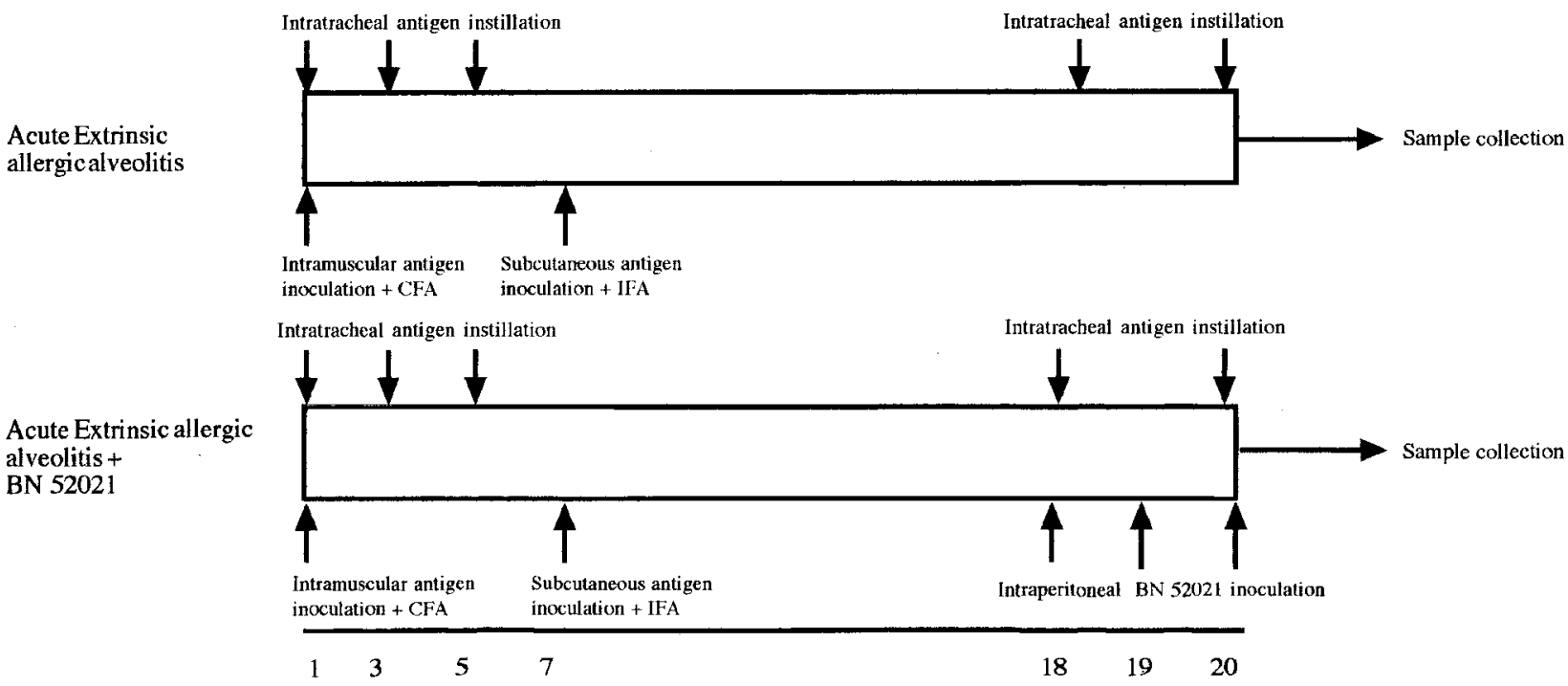

Time interval (days)

FIG. 1. Experimental protocol. CFA: Complete Freund adjuvant; IFA: Incomplete Freund adjuvant 
aliquots $(3 \times 4 \mathrm{ml})$. A $2 \mathrm{ml}$ aliquot of bronchoalveolar lavage fluid (BALF) was immediately processed for PAF determination (see below). The rest of the fluid was filtered through sterile gauze and then centrifuged at $500 \times \boldsymbol{g}$ for $10 \mathrm{~min}$ at $4^{\circ} \mathrm{C}$. The supernatant was immediately frozen at $-70{ }^{\circ} \mathrm{C}$ and the cells were resuspended in $2 \mathrm{ml}$ of phosphate-buffered saline.

Blood was obtained by direct intracardiac puncture. A $1 \mathrm{ml}$ aliquot was used for PAF determination (see below) and the rest was used to obtain serum, which was then stored at $-70^{\circ} \mathrm{C}$.

The lungs were then dissected and weighed. A small sample of the inferior right lobe (by convention) was excised, weighed and processed for PAF extraction.

\section{Cytological studies of BAL}

BAL cells were counted on a haemocytometer and viability was assessed by Trypan blue exclusion. Cytocentrifuge preparations were stained with DiffQuik® (American Scientific, McGaw Park, IL) and a differential count was performed, 200 cells being counted by two observers (T.M, M.LS.). Non-specific esterase and $\beta$-glucuronidase stains were performed using commercially available reagents (Sigma Chemical Company). Results for $\beta$-glucuronidase stain were expressed both as the percentage of positive cells and as intensity score according to Roodman (0: absence of staining; 1: weak (less than $25 \%$ cytoplasm stained); 2: moderate ( $25 \%$ to $50 \%$ cytoplasm is tained) and 3 : intense (more than $50 \%$ stained). ${ }^{18}$

\section{Studies of BALF}

BAL fluid aliquots were used for the determination of protein concentration, lactic dehydrogenase (LDH) activity, alkaline phosphatase activity and tartratesensitive acid phosphatase activity. All measurements were carried out on the same day and under the same conditions to avoid interassay variability.

Total protein concentration was assayed by an automated cholorimetric method ${ }^{19}$ using reagents provided by Boehringer Mannheim. Concentrations were expressed in micrograms per millilitre. The detection limit was $65 \mu \mathrm{g} / \mathrm{ml}$ and the intra-assay coefficient of variation was $3.45 \%$

All enzymatic activities were measured at $37^{\circ} \mathrm{C}$ by automated colorimetric methods ${ }^{20,21}$ using reagents provided by Boehringer Mannheim and results were reported as $\mathrm{U} / \mathrm{l}$. The detection limit for $\mathrm{LDH}$ (EC 1.1.1.27) was $0.73 \mathrm{U} / \mathrm{l}$ and the intraassay coefficient of variation was $2.4 \%$ The detection limit for alkaline phosphatase (E.C. 3.1.3.1) was $0.58 \mathrm{U} / 1$ and the intraassay coefficient of variation was $2.26 \%$ Tartratesensitive acid phosphatase activity was calculated by the difference between total and tartrate-resistant activity. The detection limit of total acid phosphatase
(EC 3.1.3.2) and tartrate-resistant acid phosphatase were respectively $0.01 \mathrm{U} / 1$ and $0.025 \mathrm{U} / 1$ with an intraassay coefficient of variation of $1.5 \%$ and $7.27 \%$

\section{Serum studies}

Serum aliquots were used for the determination of total protein concentration, serum electrophoretic protein profile, LDH activity, alkaline phosphatase activity and tartrate-sensitive acid phosphatase activity. All measurements were carried out on the same day and under the same conditions to avoid interassay variability.

Total protein concentration was analysed by an automated colorimetric method ${ }^{22}$ using reagents provided by Boehringer Mannheim. Concentrations were expressed in grams per decilitre. The detection limit was $0.126 \mathrm{~g} / \mathrm{dl}$ and the intraassay coefficient of variation was $1.21 \%$ Electrophoresis on cellulose acetate was used for separation of serum proteins. The percentage of each fraction was measured automatically (Olympus Hyte-System 310) after staining protein bands with Ponceau red. Results were reported as concentration of each fraction.

Serum enzyme activities were measured using the same techniques as for the bronchalveolar lavage fluid. The detection limit of serum $\mathrm{LDH}$ was $1.7 \mathrm{U} / \mathrm{l}$ and the intraassay coefficient of variation was $0.53 \%$ For serum alkaline phosphatase the detection limit was $1.38 \mathrm{U} / \mathrm{l}$ and the intraassay coefficient of variation was $1.1 \%$ The detection limit of total serum acid phosphatase was $1.02 \mathrm{U} / 1$ and the intraassay coefficient of variation was $7.38 \%$ and in the case of serum tartrate-resistant acid phosphatase the detection limit was $0.2 \mathrm{U} / 1$ and the intraassay coefficient of variation $3.13 \%$

Specific antibodies against $F$ rectivirgula were detected by double diffusion in $\operatorname{agar}^{23}$ using a commercial filtered antigen (Mercia Diagnostics Limited, UK). Positive and negative control sera were also provided by Mercia Diagnostics.

\section{PAF extraction and determination}

Freshly extracted BAL, blood and lung tissue were immediately mixed with ice-cold acidified methanol and PAF extracted was performed from the methanol phase by a modification of a previously described method. ${ }^{24}$

BAL fluid $(2 \mathrm{ml})$ was mixed with $6 \mathrm{ml}$ of ice-cold acidified methanol (Panreac) containing phenylmethyl-sulphonyl-fluoride (PMSF Sigma Chemical Company) at final concentration of $10^{-4} \mathrm{M}$. After vigorous agitation, $8 \mathrm{ml}$ of chloroform were added and after homogenization, the sample was centrifuged at $3500 \mathrm{rpm}$ for $10 \mathrm{~min}$ (BHG-Hermle Z $360 \mathrm{~K})$. The chloroform phase was separated and fresh chloroform added to the methanol phase. The 
procedure was repeated and the combined chloroform extracts dried under nitrogen. Samples were stored at $-20^{\circ} \mathrm{C}$ until reconstitution for PAF measurement.

A $1 \mathrm{ml}$ sample of blood was mixed with $5 \mathrm{ml}$ of ice-cold acidified methanol immediately after cardiac puncture. After vigorous agitation, the sample was slowly stirred for $30 \mathrm{~min}$ and then centrifuged at $3500 \mathrm{rpm}$ for $10 \mathrm{~min}$. The supernatant was retained and the pellet resuspended in $5 \mathrm{ml}$ of ice-cold acidified methanol. The methanol extracts were pooled and chloroform and water were added to give a methanol: chloroform: water ratio of 1:1:0.9, and gently stirred. After phase formation by centrifugation, the chloroform phase was removed and the methanol: water phase extracted with a further similar volume of chloroform. The chloroform extracts were pooled and dried under nitrogen.

Lung tissue was mixed with $5 \mathrm{ml}$ of cold acidified methanol, subjected to mechanical disruption at $9000 \mathrm{~g}$ for $30 \mathrm{~s}$ (Polytron PT 10-35 Kinematica AG Kriens-Luzern Switzerland) and then slowly stirred for $30 \mathrm{~min}$. The tubes were centrifuged and the pellet was again mixed with $5 \mathrm{ml}$ of acidified methanol. The methanol extracts were pooled and PAF extracted and processed as for blood.

PAF extraction from chloroform phases was performed with Bond-Elut C-18 cartridges (Varian, Cambridge, UK). The cartridges were rinsed sequentially with $2 \mathrm{ml}$ of methanol, $2 \mathrm{ml}$ of distilled water and $2 \mathrm{ml}$ of acetic acid 10\% Samples were resuspended in $2 \mathrm{ml}$ of acidified chloroform and applied to the cartridge. Columns were eluted sequentially with two $1 \mathrm{ml}$ aliquots of acetic acid, three $2 \mathrm{ml}$ aliquots of ethyl ace tate and one $6 \mathrm{ml}$ aliquot of methanol. The last fraction containing PAF was collected and dried under nitrogen. With this method the mean recovery obtained, using ${ }^{3} \mathrm{H}-\mathrm{PAF}$ as tracer, was $57 \pm$ $3.5 \%$

PAF determination was performed by radioimmunoassay (New England Nuclear Division, Dreiteich, Germany) following the instructions enclosed with the product. Briefly, dried samples were resuspended in $2 \mathrm{ml}$ of working assay buffer $(0.1$ sodium acetate and $0.05 \%$ Tween 20 in $50 \mathrm{mM}$ sodium citrate buffer, $\mathrm{pH}$ 6.3). Primary antibody solution $(100 \mu \mathrm{l})$ was added to $100 \mu \mathrm{l}$ of each sample and incubated for $15 \mathrm{~min}$ at room temperature. Then $100 \mu \mathrm{l}$ of secondary antibody/tracer solution $\left({ }^{125} \mathrm{I}-\mathrm{PAF}, 0,15 \mu \mathrm{Ci} / \mathrm{ml}\right)$ were added to each tube and incubated $15-24 \mathrm{~h}$ at room temperature. Bound and free antigen were separated by centrifugation $(1000-2000 \times \boldsymbol{g}$ for $30 \mathrm{~min}$ ) and decantation after adding $2 \mathrm{ml}$ of assay buffer to each tube. A standard curve was made using concentrations of $0.3-30 \mathrm{ng} / \mathrm{ml}$. Nonspecific binding $(3 \%)$ was determined in four tubes without antibody solution and total binding was calculated in four tubes without unlabelled antigen.
Anti-PAF antibodies were assayed for cross-reactivity against several compounds with the following results: arachidonic acid $0.002 \%$ phosphatidylcholine $0.06 \%$ phos phatidylethanolamine $0.03 \%$ and lysoPAF $0.003 \%$

After PAF ex traction, several concentrations of PAF were added to five aliquots from a sample and measurements by radioimmunoassay were used to calculate the recovery and accuracy of the method. The mean recovery observed was $88 \pm 5 \%$ The intraassay variation coefficient was $8.5 \% \pm 0.5 \%(n=$ $5)$ and the intraassay variation coefficient was $9.3 \% \pm$ $0.7 \%(n=4)$.

\section{Lung index}

The lungs, with trachea intact, were isolated and weighed to determine lung index, defined as follows. ${ }^{25}$

$$
\text { Lung index }=\frac{\text { Lung weight } / \text { Body weight test animal }}{\text { Lung weight } / \text { Body weight normal animal }}
$$

\section{In vitro secretion of acid phosphatase by guinea-pig AMs}

AMs were recovered from normal guinea pigs by BAL which was performed using $20 \mathrm{ml}$ of pyrogen-free saline in five aliquots $(4 \times 5 \mathrm{ml})$. The BAL fluid was first filtered through sterile gauze and centrifuged on a Ficoll-Hypaque gradient $\left(450 \times \boldsymbol{g}, 30 \mathrm{~min}\right.$ at $\left.20^{\circ} \mathrm{C}\right)$. After separation and two washings with sterile PBS, cells were resuspended in RPM 1640 supplemented with $10 \%$ FCS (fetal calf serum), 2 mM glutamine and penicillin-streptomicin (complete medium).

Cells were plated in four culture plates (Costar) in $1 \mathrm{ml}$ of complete medium and allowed to adhere for $2 \mathrm{~h}$ at $37^{\circ} \mathrm{C}, 5 \% \mathrm{CO}_{2}$. Non-adherent cells were removed and $1 \mathrm{ml}$ of fresh medium was added. Cells were incubated alone or with $300 \mu \mathrm{M}$ BN52021, opsonized zymosan $(400 \mu \mathrm{g} / \mathrm{ml})$ and both BN 52021 and opsonized zymosan (BN52021 was added $15 \mathrm{~min}$ before the zymosan). After $24 \mathrm{~h}$ at $37^{\circ} \mathrm{C}, 5 \% \mathrm{CO}_{2}$, the supernatant was collected and $400 \mu \mathrm{l}$ of sucroseEDTA buffer added to the cell monolayer. The cells were lysed by six freeze-thawing cycles. Acid phosphatase and $\mathrm{LDH}$ were measured in the supernatant and in the cell lysate.

\section{Statistical analysis}

Statistical analysis was performed using the unpaired $t$-test, simple linear regression and one or two tailed ANOVA using the Statworks ${ }^{\mathrm{TM}}$ and Statview ${ }^{\mathrm{TM}}$ software program for the Apple Macintosh ${ }^{\mathrm{TM}}$. Data are expressed as means $\pm \mathrm{SD}$. For comparisons, $P$ values $<$ 0.05 are considered as significant. 
Table 1. Elemental parameters in study groups

\begin{tabular}{|c|c|c|c|c|c|c|c|c|}
\hline & \multicolumn{8}{|c|}{ Groups } \\
\hline & \multicolumn{2}{|c|}{$\begin{array}{c}\text { Control } \\
(n=6)\end{array}$} & \multicolumn{2}{|c|}{$\begin{array}{c}\text { Control } \\
+\underset{\substack{(n=6) \\
(n=62021}}{ }\end{array}$} & \multicolumn{2}{|c|}{$\begin{array}{l}\text { Acute EAA } \\
\qquad(n=6)\end{array}$} & \multicolumn{2}{|c|}{$\begin{array}{c}\text { Acute EAA } \\
+ \text { BN } 52021 \\
(n=6)\end{array}$} \\
\hline & Mean & SD & Mean & SD & Mean & SD & Mean & $\mathrm{SD}$ \\
\hline $\begin{array}{l}\text { Total cell counts } \\
\left(\times 10^{6} / \mathrm{ml} \mathrm{BALF}\right)\end{array}$ & 0.49 & 0.26 & 0.89 & 0.44 & $1.96^{a, b}$ & 1.18 & $1.77^{a, b}$ & 0.80 \\
\hline $\begin{array}{l}\text { BALF MPS cells } \\
\left(\times 10^{4} / \mathrm{ml} \text { BALF }\right)\end{array}$ & 49.2 & 32.0 & 77.2 & 37.8 & $97.3^{\mathrm{a}}$ & 37.3 & $96.0^{\mathrm{a}}$ & 39.3 \\
\hline $\begin{array}{l}\text { BALF lymphocytes } \\
\left(\times 10^{4} / \mathrm{ml} \mathrm{BALF)}\right.\end{array}$ & 0.1 & 0.3 & 0.2 & 0.4 & $2.16^{a, b}$ & 1.1 & $0.2^{c}$ & 0.4 \\
\hline $\begin{array}{l}\text { BALF neutrophils } \\
\text { (× } 10^{4} / \mathrm{ml} \mathrm{BALF)}\end{array}$ & 0.2 & 0.4 & 0.1 & 0.2 & 0.4 & 1.2 & 0.1 & 0.2 \\
\hline $\begin{array}{l}\text { BALF eosinophils } \\
\left(\times 10^{4} / \mathrm{ml} \mathrm{BALF)}\right.\end{array}$ & 28.6 & 28.3 & 11.6 & 5.1 & $109.1^{a, b}$ & 95.4 & $81.8^{a, b}$ & 49.5 \\
\hline Lung index & 0.9 & 0.12 & 1.01 & 0.08 & $1.70^{a, b}$ & 0.30 & $1.40^{c}$ & 0.20 \\
\hline $\begin{array}{l}\text { BALF total protein } \\
(\mu \mathrm{g} / \mathrm{ml})\end{array}$ & 80 & 15.5 & 91 & 28.5 & $191^{a, b}$ & 133 & 162 & 89 \\
\hline
\end{tabular}

EAA: Extrinsic allergic alveolitis; BALF: bronchoalveolar lavage fluid; MPS: mononuclear phagocyte system.

a $P<0.05$ compared with control group:

b $P<0.05$ compared with control + BN 52021 group;

c $P<0.05$ compared with EAA group.

\section{Results}

\section{Validation of the animal model}

In order to verify that the animals subjected to the experimental protocol had developed a disease characteristic of extrinsic allergic alveolitis, different parameters were evaluated. Initially we observed that precipiting antibodies to Faenia rectivốrgula appeared in the serum of all the guinea-pigs inoculated intratracheally with particulate antigen. Moreover, in this experimental group there was an intense

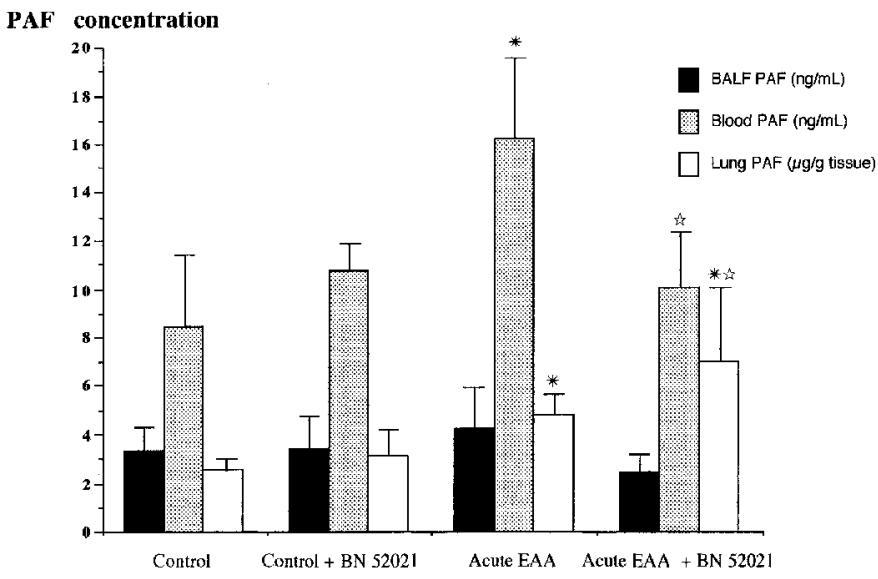

FIG. 2. PAF concentrations in the experimental groups. Data are mean \pm SD of triplicate measurements from three guinea pigs/group and were analysed by two-way analysis of variance and multiple mean comparison test. Asterisks ( $\star$ ) represent significant differences $(P<0.05)$ with respect to control group and stars (ఓ) significant differences $(P<0.05)$ with respect to the acute EAA group. alveolitis (mainly mononuclear phagocyte system cells and eosinophils), and a rise in the lung index and in protein concentration in the BALF (Table 1).

\section{PAF measurements}

The guinea pigs in the group subjected to the EAA experimental model showed a significant rise in PAF concentration in blood and lung tissue with respect to the control group (Fig. 2). However, there were no significant differences in the PAF values in the BALF, either when the results were expressed by volume unit or as total PAF recovered. Treatment with BN 52021 prior to the induction of EAA reduces PAF levels in the blood, but increases PAF concentration in the lung tissue.

\section{In vivo effect of PAF-receptor antagonist on macrophage activation}

The participation of PAF in macrophage activation was examined using two complementary methods. In vivo AM activation was examined by measuring lysosomal enzyme activities (in both intra and extracellular compartments) in the animal model in the presence or absence of an inhibitor of PAF receptors (BN 52021). In the guinea pigs subjected to the EAA experimental model there was a decrease in intramacrophage lysosomal enzymes activity (Fig. 3) and an increase in extracellular activity in both BALF and serum (Fig. 4). Treatment with BN 52021 prior to EAA induction significantly reduced the release of lysoso- 
mal enzymes as the percentage and the score of $\beta$-glucuronidase were higher than in the acute EAA group. Moreover, there was less tartrate-sensitive acid phosphatase activity in BALF and in serum if the animals were pretreated with BN 52021 before being subjected to the EAA model.

\section{In vitro effect of PAF-receptor antagonist on macrophage activation}

We also studied the effect of BN 52021 in vivo on the release of lysosomal enzymes in the alveolar macro-

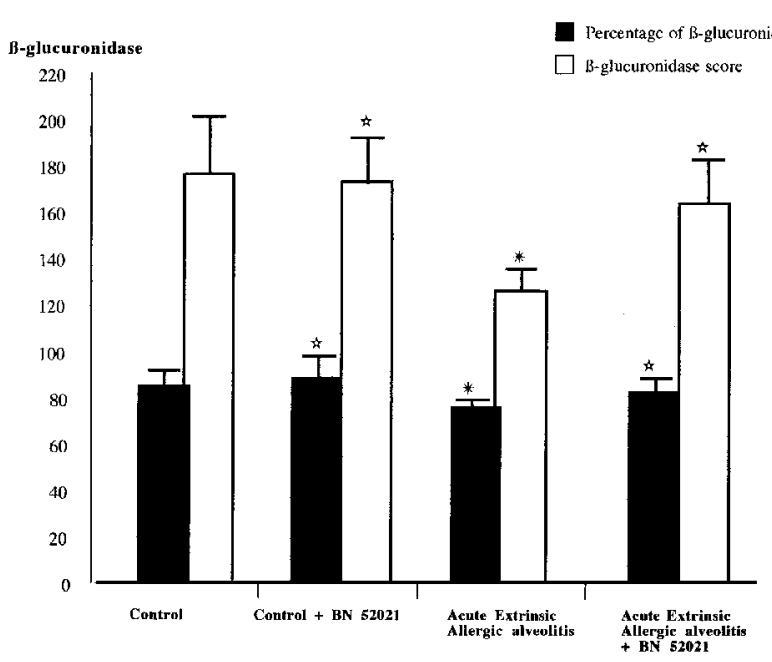

FIG. 3. In vivo effect of BN52021 on intracellular lysosomal enzymes. Data are mean \pm SD of six guinea pigs/group and were analysed by one-way analysis of variance and multiple mean comparison test. Asterisks $(\star)$ represent significant differences $(P<0.05)$ with respect to control group and stars (is) significant differences $(P<0.05)$ with respect to the acute EAA group. phages of control guinea pigs stimulated by a particulate antigen. The results (Fig. 5) indicate that preincubation with BN 52021 inhibited significantly the release of lysosomal enzymes both after stimulation with the particulate antigen and in basal conditions. Simultaneous measurement of $\mathrm{LDH}$ in the supernatant and in the cell lysate showed that the release of lysosomal enzymes to the culture was an active process since $25-45 \%$ acid phosphatase was released as against $10-13 \%$ of $\mathrm{LDH}$.

\section{Effect of PAF-receptor antagonism on parenchymal lung injury}

The effect of PAF on parenchymal lung injury was evaluated by measuring the effect of BN52021 on lung parenchymatous lesion indices (lung index, BALF LDH activity and BALF alkaline phosphatase activity) and parameters of systemic reponse to the challenge (acute phase reagents).

In our study we observed that treatment with $\mathrm{BN}$ 52021 prior to EAA induction significantly reduced the lung index (Table 1). Although the lung index is non-specific, since many factors intervene in lung weight, the notable decrease induced by the PAF antagonist clearly indicates a reduction of the inflammatory component in the lung parenchyma.

The total protein concentration in the BALF is a useful index in the evaluation of lung lesion in interstitial diseases. In our study, the use of BN 52021 in EAA affected this parameter in a similar way to the lung index (Table 1).

In this study maximum values of BALF LDH activity were detected in the acute EAA group and treatment with BN 52021 prior to EAA induction

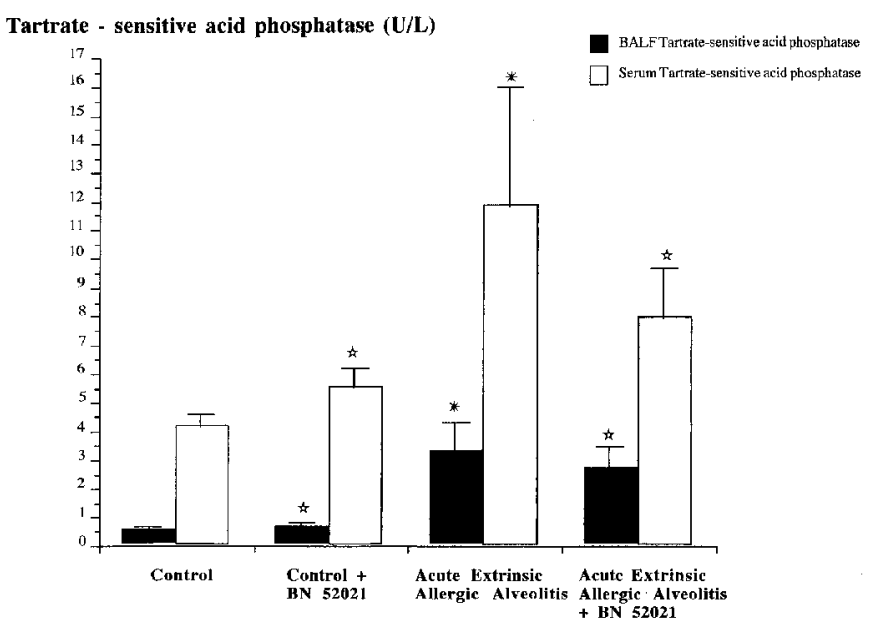

FIG. 4. In vivo effect of BN52021 on extracellular lysosomal enzymes. Data are mean \pm SD of six guinea pigs/group and were analysed by one-way analysis of variance and multiple mean comparison test. Asterisks $(\star)$ represent significant differences $(P<0.05)$ with respect to control group and stars ( $\lesssim$ ) significant differences $(P<0.05)$ with respect to the acute EAA group.

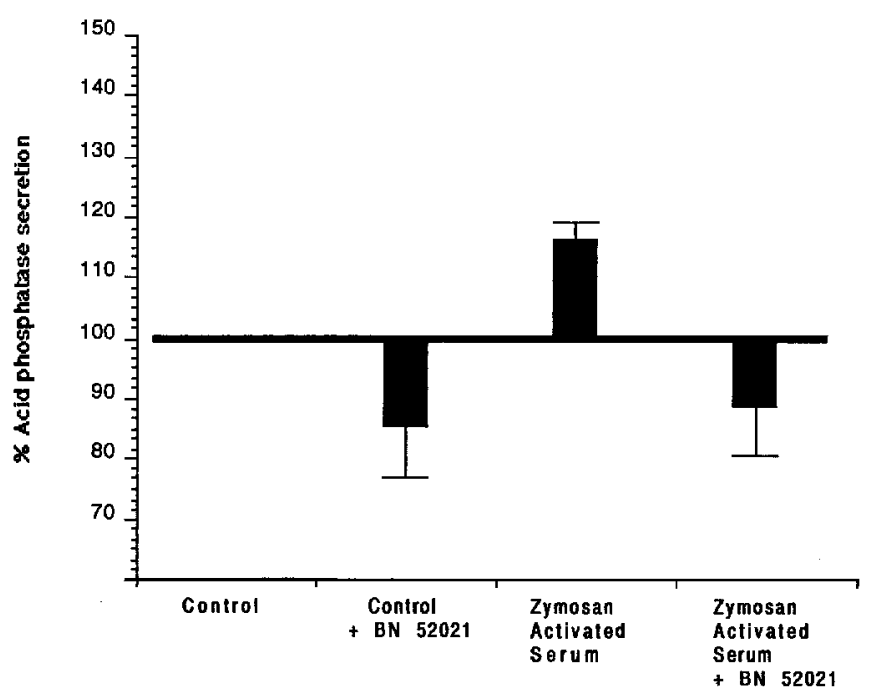

FIG. 5. Effect of BN52021 in vitro on alveolar macrophage lysosomal enzyme release. Each column shows mean \pm SEM of values obtained in three separate experiments. Results are expressed as percentage of the control group value (=100\%). 
Table 2. LDH and alkaline phosphatase values

\begin{tabular}{|c|c|c|c|c|c|c|c|c|}
\hline & \multicolumn{8}{|c|}{ Groups } \\
\hline & \multicolumn{2}{|c|}{$\begin{array}{l}\text { Control } \\
(n=6)\end{array}$} & \multicolumn{2}{|c|}{$\begin{array}{c}\text { Control } \\
+ \text { BN } 52021 \\
(n=6)\end{array}$} & \multicolumn{2}{|c|}{$\begin{array}{l}\text { Acute EAA } \\
\qquad(n=6)\end{array}$} & \multicolumn{2}{|c|}{$\begin{array}{c}\text { Acute EAA } \\
+ \text { BN } 52021 \\
(n=6)\end{array}$} \\
\hline & Mean & SD & Mean & SD & Mean & SD & Mean & $\mathrm{SD}$ \\
\hline $\begin{array}{l}\text { BALF LDH activity } \\
(U / I)\end{array}$ & 0.89 & 0.42 & 1.07 & 0.36 & $97.17^{a, b}$ & 36.8 & $1.93^{c}$ & 0.90 \\
\hline $\begin{array}{l}\text { Serum LDH activity } \\
(U / I)\end{array}$ & 619 & 110 & 426 & 96 & 557 & 277 & 522 & 150 \\
\hline $\begin{array}{l}\text { BALF al kaline } \\
\text { phosphatase (U/l) }\end{array}$ & 5.1 & 2.0 & 11.2 & 3.0 & $33.6^{a, b}$ & 17.0 & $37.9^{a, b}$ & 11.0 \\
\hline $\begin{array}{l}\text { Serum alkaline } \\
\text { phosphatase (U/l) }\end{array}$ & 629 & 113 & 647 & 38 & $331^{a, b}$ & 1.2 & $461^{c}$ & 118 \\
\hline
\end{tabular}

a $P<0.05$ compared with control group;

${ }^{b} P<0.05$ compared with control + BN 52021 group

c $P<0.05$ compared with EAA group.

Table 3. Electrophoretic serum protein profile

\begin{tabular}{|c|c|c|c|c|c|c|c|c|}
\hline & \multicolumn{8}{|c|}{ Groups } \\
\hline & \multicolumn{2}{|c|}{$\begin{array}{l}\text { Control } \\
(n=6)\end{array}$} & \multicolumn{2}{|c|}{$\begin{array}{c}\text { Control } \\
+ \text { BN } 52021 \\
(n=6)\end{array}$} & \multicolumn{2}{|c|}{$\begin{array}{l}\text { Acute EAA } \\
\qquad(n=6)\end{array}$} & \multicolumn{2}{|c|}{$\begin{array}{c}\text { Acute EAA } \\
+ \text { BN } 52021 \\
(n=6)\end{array}$} \\
\hline & Mean & $\mathrm{SD}$ & Mean & SD & Mean & SD & Mean & SD \\
\hline $\begin{array}{l}\text { Albumin (g/dl) } \\
\alpha \text {-globulin (g/dl) } \\
\beta \text {-globulin (g/dl) } \\
\gamma \text {-globulin (g/dl) }\end{array}$ & $\begin{array}{l}3.12 \\
1.06 \\
0.24 \\
0.17\end{array}$ & $\begin{array}{l}0.35 \\
0.10 \\
0.04 \\
0.03\end{array}$ & $\begin{array}{l}2.96 \\
1.03 \\
0.31 \\
0.17\end{array}$ & $\begin{array}{l}0.05 \\
0.05 \\
0.04 \\
0.04\end{array}$ & $\begin{array}{l}2.71^{a, b} \\
1.26^{a, b} \\
0.38^{a, b} \\
0.37^{a, b}\end{array}$ & $\begin{array}{l}0.17 \\
0.17 \\
0.05 \\
0.10\end{array}$ & $\begin{array}{l}2.50^{a, b} \\
1.14^{c} \\
0.41^{a, b} \\
0.38^{a, b}\end{array}$ & $\begin{array}{l}0.40 \\
0.07 \\
0.04 \\
0.08\end{array}$ \\
\hline
\end{tabular}

EAA: Extrinsic allergic alveolitis; BALF: bronchoalveolar lavage fluid.

${ }^{2} P<0.05$ compared with control group;

${ }^{b} P<0.05$ compared with control + BN 52021 group;

c $P<0.05$ compared with EAA group.

\section{BALF LDH activity (U/L)}

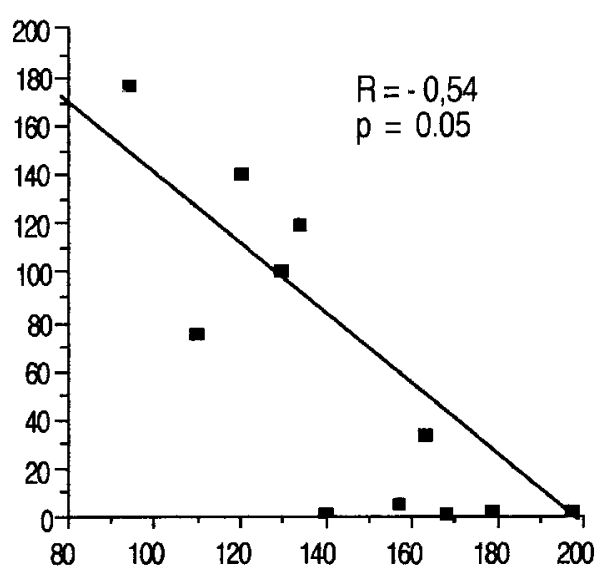

B-glucuronidase "score"
BALF LDH activity (U/L)

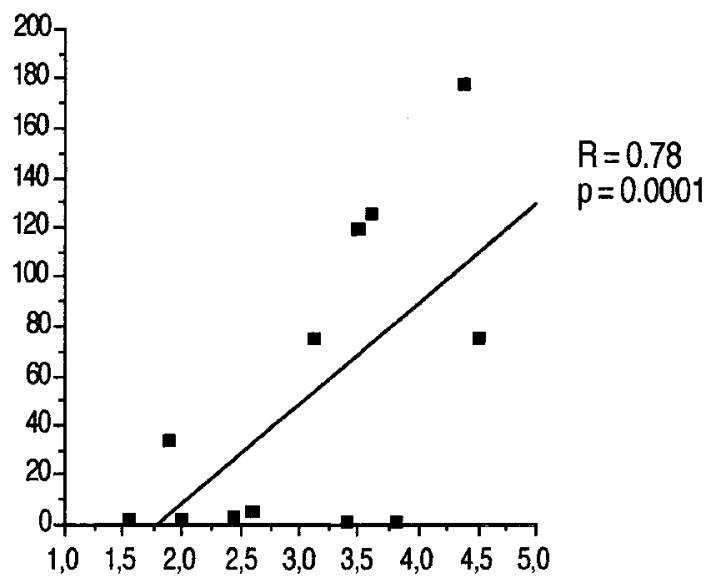

Tartrate sensitive acid phosphatase (U/L)

FIG. 6. Relationship between BALF LDH activity and lysosomal enzymes in acute EAA groups. Data were analysed by Pearson's correlation test. 
reduced BALF LDH activity to values similar to those of the controls (Table 2). The plasmatic values of $\mathrm{LDH}$ are similar in all the experimental groups (Table 2 ). On the other hand, there was a negative correlation between $\mathrm{LDH}$ catalytic activity in the BALF and intracellular lysosomal activity, and a positive correlation with tartrate-sensitive acid phosphatase activity in the BALF (Fig. 6).

Our results show a marked rise in alkaline phosphatase activity in acute EAA with respect to both control groups (Table 2). However, in contrast to the results obtained with the other lung lesion indices, prior administration of BN 52021 did not modify the activity of this enzyme in the BAL.

Guinea pigs with experimental EAA showed, as expected, an increase in the plasma electrophoretic fractions corresponding to acute phase reagents, as well as hypergammaglobulinaemia and the presence of serum precipitins (Table 3). The use of the PAF antagonist did not modify either the intensity of the immunoglobulin response or the presence of precipitins. However, guinea pigs treated with BN 52021 prior to EAA induction showed lower concentrations of the $\alpha$ globulin fraction than the acute EAA group.

\section{Discussion}

The pathogenic role of PAF in EAA was examined in a guinea-pig model. We first verified, using various parameters, the validity of the model. Although there are no criteria unanimously established in the literature, since our experimental model combines the isolated criteria used separately by other authors, we are confident that it is adequate. ${ }^{26-31}$

Subsequently, we measured the concentration of PAF in BALF, blood and lung tissue in order to evaluate the overall participation of PAF in the acute phase of EAA. Our results showed a significant rise in PAF concentration in blood and lung tissue with respect to the control group, but no significant differences in the PAF values in the BALF. These data are similar to those obtained by Chang et al. ${ }^{32}$ after peritoneal administration of endotoxin in rats. The discrepancy between the results obtained in lung tissue and in BALF can be explained by compartmentalization of the inflammatory response in the lung interstitium and/or by in situ degradation of the PAF mediated by acetylhydrolase in the alveolar region. In fact, an increase in number of macrophages in the lung of animals with EAA might be expected to cause local increases in PAF acetylhydrolase activity. ${ }^{33}$ Another suggestive explanation of the absence of PAF in the BALF is its retention by alveolar cells because of the high affinity of this lipid mediator for the membranes. Treatment with BN 52021 prior to the induction of EAA reduces PAF levels in the blood, but increases PAF concentration in the lung tissue. One possible explanation for this finding is the different regulation of PAF synthesis in diverse body compartments. Thus, although in some tissues PAF may have a positive autocrine stimulation of PAF synthesis, in the lung blockade of PAF receptors could increase free-PAF However, PAF concentration in blood, which can be interpreted as the net result of the production by the different tissues, decreases on administering the PAFreceptor antagonist.

The preadministration of PAF-receptor antagonism reduces in vivo lysosomal enzymatic release (measured by biochemical and cytochemical methods) but does not abolish enzyme release in response to particulate antigens. In order to confirm this interpretation, AMs from healthy guinea pigs were cultivated in the presence of a particulate antigen, since under these conditions, enzymes are released to the extracellular environment. ${ }^{15}$ The results indicate that preincubation with BN 52021 inhibited the active release of lysosomal enzymes both after stimulation with the particulate antigen and in basal conditions. It should be noted that there was a difference between the effect of BN 52021 in vivo, where there was no change in lysosomal enzymatic release, and the results obtained in vitro. This may be an experimental artifact, as manipulation of the cells, and even adherence to the plastic, can cause PAF release. Hence, it can be concluded that inhibition of PAF receptors reduces lysosomal enzyme release both in vivo and in vitro. These results are similar to those obtained in monocytes by Shen et al. ${ }^{14}$ who demonstrated that release of lysosomal enzymes was inhibited by kadsurenone, another PAF-receptor antagonist.

Diverse parameters have been used in the literature to evaluate, and to some extent quantify, parenchymal lung injury. Those most commonly used in lung lesion experimental models are the lung index, protein concentration in BALF, LDH activity and alkaline phosphatase activity. The lung index is an easily obtained parameter which indicates the existence of a pulmonary inflammatory phenomenon. This index was first described by Wilson et al. ${ }^{25}$ and validated by other authors. ${ }^{31}$ In our study we observed that treatment with BN 52021 prior to EAA induction significantly reduced the lung index. Although the lung index is non-specific, since many factors intervene in lung weight, the notable decrease induced by the PAF antagonist clearly indicates a reduction of the inflammatory component in the lung parenchyma. Similar results were obtained when we evaluated the total protein concentration in the BALF.

BALF LDH activity measurement has been used as a lung lesion index in diverse experimental model ${ }^{34,35}$ and in human diseases. ${ }^{36,37}$ Since this is a cytoplasmic enzyme, its presence in a biological fluid indicates cytolysis. Although it is not very likely, owing to the pulmonary location of the inflammation, this enzyme could also come from the plasma and cross the 
alveolocapillary barrier due to the increase in permeability which takes place in acute EAA. How ever, in our study we can reasonably reject this origin since the plasmatic values of $\mathrm{LDH}$ are similar in all the experimental groups. Hence, we can conclude that inhibition of the effects of PAF on the lung parenchyma gives rise to a decrease in local cell destruction. If one takes into account the fact that activated macrophages are more sensitive to destruction after phagocytosis ${ }^{38}$ and the stabilizing effect of BN52021 on macrophage lysosomes, then the decreased BALF LDH levels may be due to the decrease in macrophage activation. In support of this proposal we found a negative correlation between LDH catalytic activity in the BALF and intracellular lysosomal activity, and a positive correlation with tartrate-sensitive acid phosphatase activity in the BALF.

Alkaline phosphatase activity in the lower respiratory tract is limited to type II pneumocytes. ${ }^{39}$ Measurement of this enzyme activity in the BALF has been used as an index of lesion and/or proliferation of these cells. ${ }^{40,41}$ Since in acute EAA there is an hypertrophy of type II pneumocytes as well as notable structural alterations in these cells, ${ }^{42}$ we used this measurement to evaluate their involvement. Our results show a marked rise in alkaline phosphatase activity in acute EAA with respect to both control groups. However, in contrast to the results obtained with the other lung lesion indices, prior administration of BN 52021 did not modify the activity of this enzyme in the BAL One possible reason for this discrepancy is the great avidity of the type II pneumocytes for PAF, 95\% of the radiolabelled PAF instilled into the rat lung airways being selectively retained by these cells. ${ }^{43}$ Since this effect is not antagonized by BN 52021 and the high lipid content of these cells, it is possible that PAF-type II pneumocyte interaction is not mediated by receptors.

In summary, the data from this paper suggest that lung lesions from acute EAA are partly mediated by local production of PAF through modulation of AM activation.

\section{References}

1. Roberts RC, Moore VL Immunopathogenesis of hypersensitivity pneumonitis. Am Rev Respir Dis 1977; 116: 1075-1090.

2. Calvanico NJ, Ambegaonkar SN, Schlueter DP, Fink JN. Immunoglobulin levels in bronchoalveolar lavage from pigeon breeders. J Lab Clin Med 1980; 96: 129-140.

3. Pérez Arellano JL, Sánchez R, Pastor I, Losa JE, Garcâa MJ, González Villarón L. Pathogenesis of hypersensitivity pneumonitis. Allergol Im munopathol 1989; 17: 225-232.

4. Costabel U. The alveolitis of hypersensitivity pneumonitis. Eur Respir J 1988; 1: 5-9.

5. Adams DO, Hamilton TA. The cell biology of macrophage activation. Ann Rev Immunol 1984; 2: 283-318.

6. Pérez-Arellano JL, Barrios MN, Martôn T, Sánchez ML, Jiménez A, González-Buitrago JM. Hydrolytic enzymes of the alveolar macrophage in diffuse pulmonary interstitial disease. Respir Med 1996; 90: 159-166.

7. Pérez-Arellano JL, Barrios MN, Martôn T, Sánchez ML, Jiménez A, González-Buitrago JM. Role of lysosomal enzymes released by alveolar macrophage in the pathogenesis of the acute phase of hypersensitivity pneumonitis. Med Inflam 1995; 4: 43-48.
8. Camussi G, Pawloski I, Tetta C, Roffinello C, Alberton M, Bretjens J, Andres G. Acute lung inflammation induced in the rabbit by local instillation of 1-O-Octadecyl-2-acetyl-sn-glyceryl-3 phosphorylcholine or of native platelet-activating factor. Am J Pathol 1983; 112: 78-88.

9. Albert DH, Snyder F. Release of arachidonic acid from 1-alkyl-2 acyl-snglycero-3-phosphocholine, a precursor of platelet-activating factor, in rat alveolar macrophages. Biochem Biophys Acta 1984; 796: 92-101.

10. Arnoux B, Joseph M, Simoes MH,TonnelAB, Duroux P, CapronA.Antigenic release of PAF-acether and $\beta$-glucuronidase from alveolar macrophages of asthmatics. Bull Eur Physiopathol 1987; 23: 119-124.

11. Warren JS, Barton PA, Mandel DM, Matrosic K. Intrapulmonary tumor necrosis factor triggers local platelet-activating factor production in rat immune complex alveolitis. Lab Invest 1990; 63: 746-754.

12. Kadiri C, Cherqui G, Masliah J, Rybkine T, Etienne J, Bereziat G Mechanism of N-formyl-methionyl-teucyl-phenylalanine and platelet activating factor-induced arachidonic acid release in guinea pig alveolar macrophages: involvement of a GTP-binding protein and role of proteinkinase A and protein kinase C. Mol Pharmacol 1990; 28: 418-425.

13. Schaberg T, Haller $H$, Lode $H$. Evidence for a platelet-activating factor receptor on human alveolar macrophages. Biochem Biophys Res Commun 1991; 177: 704-710.

14. Shen TY, Hwang SB, Chang MN, Doebber TW, Lam MH, Wu MS Characterization of a platelet-activating factor receptor antagonist from haifenteng (Piper futokadsura): specific inhibition of in vitro and in vivo platelet activating factor-induced effects. Proc Natl Acad Sci (USA) 1985; 82: 672-676.

15. Speziale SC, Smith RJ. Effects of soluble stimuli on human monocyte secretion. Clin Immunol Immunopathol 1985; 36: 60-69.

16. Schuyler M, Crooks L Experimental hypersensitivity pneumonitis in guinea pigs. Am Rev Respir Dis 1989; 139: 996-1002.

17. Rodriguez Barbero A, Bosque E, Rivas Cabañero L, Arévalo M, López Novoa JM. Effect of platelet-activating factor antagonism on gentamicin nephrotoxicity. Mediators Inflamm 1992; 1: 23-26.

18. Roodman GD, Ibbotson KJ, MacDonald BR, Kuehl TJ, Mundy GR. 1,25-Dihydroxyvitamin D3 causes formation of multinucleated cells with several osteoclast characteristics in cultures of primate marrow. Proc Natl Acad Sci (USA) 1985; 82: 8213-8217.

19. Watanabe N, Kamei S, Okhubo A, Yamanaka M, Ohsawa S, Makino K, Tokuda K. Urinary protein as measured with pyrogallol red-molybdate complex, manually and in a Hitachi 726 automated analyzer. Clin Chem 1986; 32: 1551-1554.

20. Deustsche Gesellschaft für klinische chemie. Recommendations of the German Society for clinical chemistry. Z Klin Chem Klin Biochem 1972; 10: 281-291.

21. Hillmann G. Fortlaufende photometrische messung der sauren prostataphosphatase aktivität. Z Klin Chem Klin Biochem 1971; 9: 273-274.

22. Gornall AG, Bardawill CJ, David MM Determination of serum proteins by means of the Biuret reaction. J Biol Chem 1949; 177: 751-766.

23. Johnstone A, Thorpe R Precipitation techniques in agar and agarose. In: Johnstone A, Thorpe $\mathrm{R}$ eds. Immunochemistry in Practice. Oxford: Blackwell Scientific Publications, 1990; 131.

24. Caramelo C, Fernandez-Gallardo S, Iñarrea P, Santos JC, López Novoa JM, Sánchez Crespo M. Presence of platelet activating factor in blood from humans and experimental animals. Its absence in anephric individuals. Biochem Biophys Res Commun 1984; 120: 789-794.

25. Wilson BD, Sternick JL, Yoshizawa Y, Katzenstein AL, Moore V. Ex perimental murine hypersensitivity pneumonitis: multigenic control and influence by genes within the I-B subregion of the H-2 complex. J Immunol 1982; 129: 2160-2163.

26. CormierY, Gagnon L, Berubé-Genest F, Fournier M. Sequential bronchoalveolar lavage in experimental extrinsic allergic alveolitis. The influence of cigarette smoking. Am Rev Respir Dis 1988; 137: 1104-1109.

27. Kawai T, Salvaggio J, Lake W, Harris JO. Experimental production of hypersensitivity pneumonitis with bagasse and thermophilic actinomycete antigen. J Allergy Clin Immunol 1972; 50: 276-288.

28. Salvaggio J, Phanuphak P, Stanford R, Bice D, Claman H. Experimental production of granulomatous pneumonitis: comparison of imunological and morphological sequeae with particulate and soluble antigens administered via the respiratory route. JAllergy Clin Immunol 1975; 56: 364-380.

29. Schuyler M, Subramanyan S, Hassan MO. Experimental hypersensitivity pneumonitis: transfer with cultured cells. J Lab Clin Med 1987; 109: 623-630.

30. Seppä A, Jägerroos H, Mäntyjärvi RA. Experimental allergic alveolitis induced by Thermacty nomices vulgaris. APMIS 1984; 92: 125-131.

31. Takizawa H, Suko M, Kobayashi N, et al. Experimental hypersensitivity pneumonitis in the mouse: histologic and immunologic features and their modulation with cyclosporin A. J Allergy Cin Immunol 1988; 81: 391-400.

32. Chang SW, Feddersen CO, Henson PM, Voelkel NF. Platelet activating factor mediates hemodynamic changes in lung injury in endotoxintreated rats. J Clin Invest 1987; 79: 1498-1509.

33. Elstad MR, Stafforini DM, McIntyre TM et al. Platelet-activating factor acetylhydrolase increases during macrophage differentiation novel mechanism that regulates accumulation of platelet-activating factor. $J$ Biol Chem 1989; 264: 8467-8470. 
34. Forkert PG, Custer EM, Alpert AJ, Ansari GAS, Reynolds ES. Lactate dehydrogenase activity in mouse lung following 1,1,-dichloroethylene: index of airways injury. Exp Lung Res 1982; 4: 67-77.

35. Jenkinson SG, Black RD, Law rence RA. Glutathione concentrations in rat lung bronchoalveolar lavage fluid: effects of hyperoxia. J Lab Clin Med 1988; 112 : 345-351.

36. Hoffman RM, Rogers RM. Serum and lavage lactate dehydrogenase isoenzymes in pulmonary alveolar proteinosis. Am Rev Respir Dis 1991; 143: 42-46.

37. Smith RL, Ripps CS, Lewis ML. Elevated lactate dehydrogenase values in patients with Pneumocystis carinii pneumonia. Chest 1988; 93: 987-992.

38. McGee MP, Myrvik QN Phagocytosis-induced injury of normal and activated alveolar macrophages. Infect Immun 1979; 26: 910-915.

39. Edelson JD, Shannon JM, Mason RJ. Alkaline phosphatase: a marker of alveolar type II cell differentiation. Am Rev Respir Dis 1988; 138: 1268-1275.

40. Henderson RF, Mauderly JL, Pickrell JA, Hahn FF, Muhle H, Rebar AH. Comparative study of bronchoalveolar lavage fluid: effects of species, age and method of lavage. Exp Lung Res 1987; 13: 329-342.
41. Reasor MI, Nadeau D, Hook GER Extracellular alkaline phosphatase in the airways of the rabbit lung. Lung 1987; 155: 321-335.

42. Quezada AL, Gimpel SF, Miranda DO, Las Heras JB, Andreis MC. Ultrastructural features of alveolar cells in experimental hypersensitivity pneumonitis. Respiration 1987; 51: 127-136.

43. Haroldsen PE, Voelckel NF, Henson JE, Henson PM, Murphy RC Me tabolism of platelet activating factor (PAF) in the isolated perfused rat lung. J Clin Invest 1987; 79: 1860-1867.

ACKNOWLEDGEMENTS. The authors gratefully thank J. H. Brock and Charles McSharry (Department of Immunology, Western Infirmary, Glasgow) for review of the manuscript.

\section{Received 7 January 1998; \\ accepted in revised form 30 January 1998}




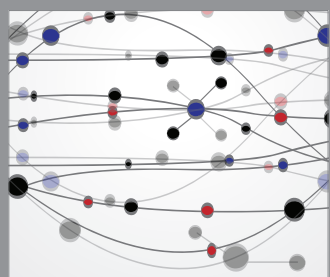

The Scientific World Journal
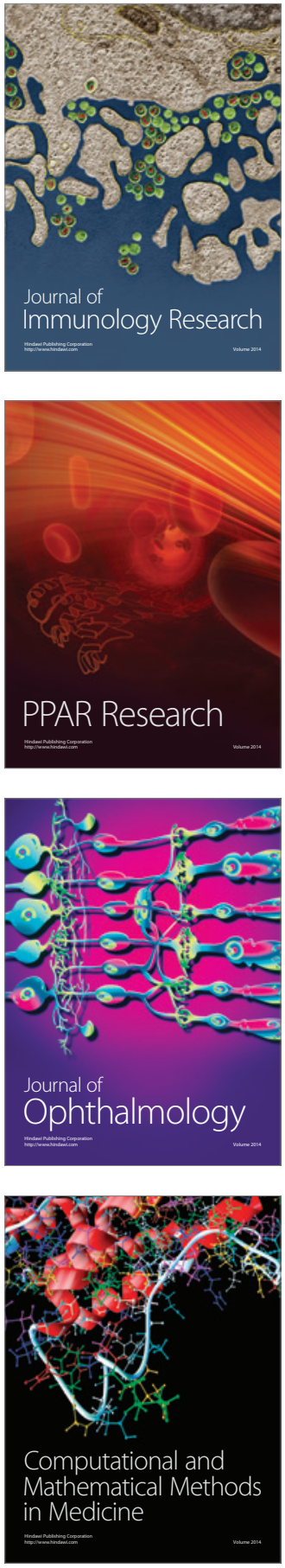

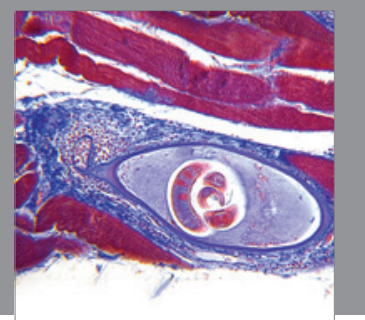

Gastroenterology

Research and Practice
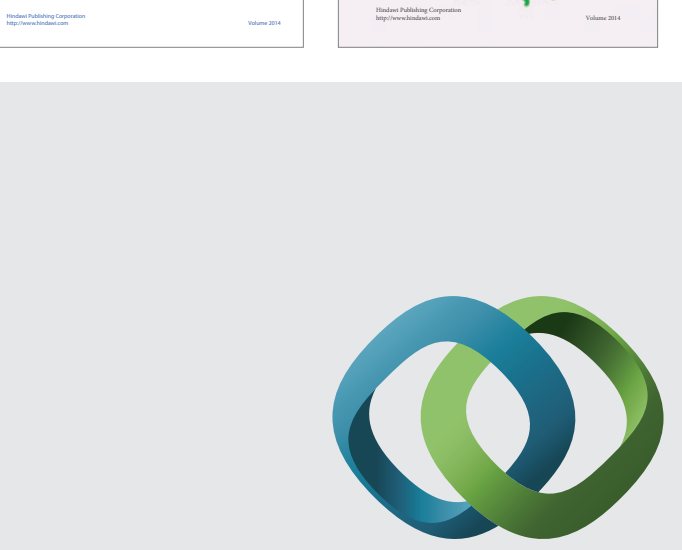

\section{Hindawi}

Submit your manuscripts at

http://www.hindawi.com
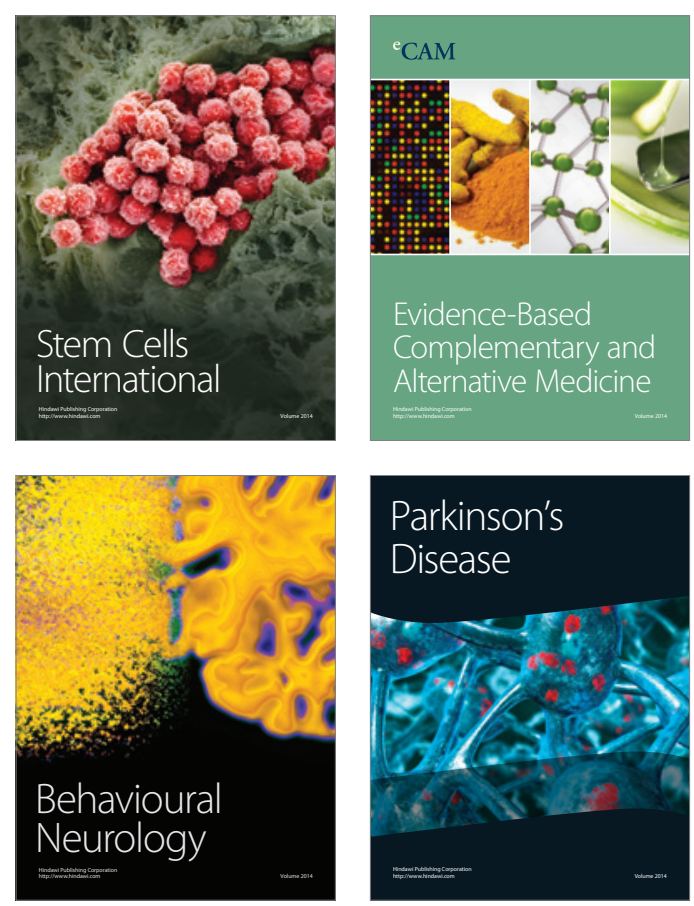

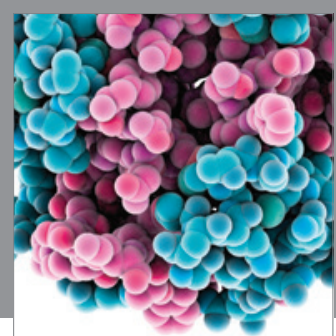

Journal of
Diabetes Research

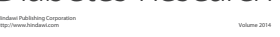

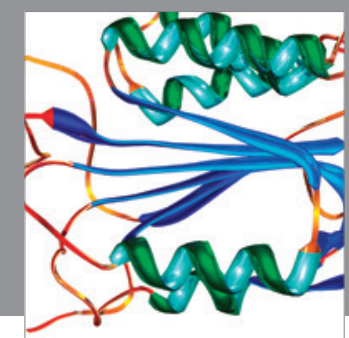

Disease Markers
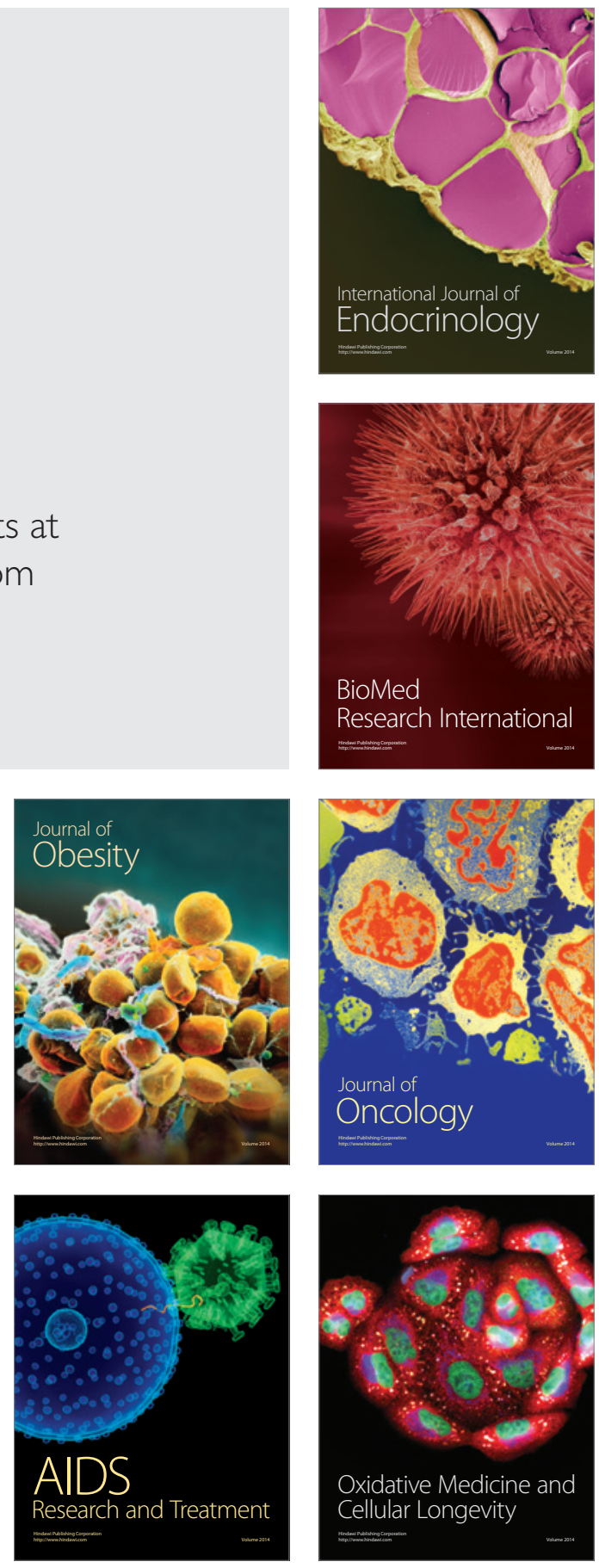